African Research Review An International Multidisciplinary Journal, Ethiopia

Vol. 10(1), Serial No.40, January, 2016: 17-25

ISSN 1994-9057 (Print)

ISSN 2070--0083 (Online)

Doi: http://dx.doi.org/10.4314/afrrev.v10i1.2

\title{
Children and Modern Day Slavery
}

\author{
Okpalaobi, B. Nkechi \\ Faculty of Law \\ Nnamdi Azikiwe University \\ Awka Anambra State, Nigeria \\ E-mail:nklobi@yahoo.com
}

\begin{abstract}
This paper examines the concept of slavery in these modern times, as it relates to and affects Children, highlighting the very many shades of the debasing scourge. It starts off by tracing its early manifestations from the time of yore, chronicling its evolution and persistence to this day. It decries the varied proliferation of Child Slavery to this modern day, juxtaposing international posture and reaction with action in relation to the anathema. It then investigates the status quo here in Nigeria, highlighting its legal perspectives, implications as well as the state of legislative cum judicial action in relation thereto, proffering lines of action for government and key policy-making institutions with a view to effectively arresting the scourge and putting it under firm check.
\end{abstract}

\section{Introduction}

Without doubt, Children remain, alongside women, some of humankind's most vulnerable lot. This is owing to a number of reasons. Children are by their very nature naïve, easily given away to daydreams and fantasies. Their limited mental, physical cum psycho-emotional build and capacity ensure they remain perpetually susceptible to vicious scheming. It is little wonder then that of the total number of people estimated to be enslaved presently the world over- a UN study puts it at between 21 to 30 million 
people by United Nation (2015) Children constitute the greatest chunk of the bulk, accounting for over 26 percent of the lot by Ilo (2012) Slavery is a hidden crime. It is illegal in all countries of the world by UN (2007) yet it remains prevalent in many forms today, where it has now come to be known as Human Trafficking. Slavery is no longer limited to the conjured images of people in chains. Slavery is defined by The Free Dictionary as "a civil relationship whereby one person has absolute power over another and controls his life, liberty and fortune as stated by Free Dictionary (2015) That is, the state or condition of being a slave as pointed out by Free Dictionary (2015) It is the subjection of a person to another person, especially in being forced into work, the brutal practice of forcing someone to work hard, without paying them a fair wage, sometimes without paying them at all. It is as it affects Children that the most gruesome effects of Slavery are felt; from teenage girls being forced into prostitution to engagement of minors in compulsory domestic labour, conscription of child soldiers in war-torn lands to millions of Children being trafficked around the world into lives of depravity and despair. The list is endless. Child Slavery is real. It persists till this day. Here, an enquiry is launched into Child Slavery as prevalent in this modern day; the vicissitudes and prospects, facts and figures that do not necessarily make for happy reading, storied accounts of grave infractions of fundamental rights of Children the world over. This discourse will be sociological as much as it is historical, with the writer's standpoint ultimately legal.

\section{Children and Modern Day Slavery; A Chronicle of the Longsuffering}

For Centuries, the Slave trade persisted in Europe and the Americas, with People being shipped away from Africa and the Caribbean, onto dire lives of forced labour and deprivation. This malaise largely persevered until most Countries decided to officially ban the trade in 1850 , Brazil remaining the last of the Slave lords, the Amazonian State eventually deciding officially to let go of the trade in 1888. The word 'Slavery' itself is taken from the Latin word 'sclava' referring to the $9^{\text {th }}$ century slavery of the Slavonic people of Central and Southeastern Europe, which came to mean anyone held in captivity by Free Dictionary (2015) Long after Slave trade was officially abolished, hybrid forms have metamorphosed and persevered the world over and Children have been the hardest hit.

Who are Children for the purposes of this discourse? According to the African Charter on the Rights and Welfare of the Child (1979) a Child is any person who has not attained eighteen years of age. The same definition obtains in Article 1 of the United Nations Convention on the Rights of the Child (1989) and in the Child Rights Act (2003) Childhood is defined by culturally set boundaries which have continued to change throughout human history. Answers to the question as to which age is acceptable for purposes of work and employment would likewise vary according to clime, but child slavery is unanimously the worst form of child labour existing and this is unacceptable and outlawed in almost all States. The laws prohibiting child labour in 
the various states of the world notwithstanding, Children are continually trafficked around and forced into lives of depravity, with their numbers running into millions and still counting. Classic instances and occasions of child slavery abound in virtually all climes. Consider for instance the Domestic servitude prevalent in most countries and more particularly here in Nigeria. This is one of the pervasive forms of modern child slavery, whereby children, majority of them girls, are kept as domestic workers in homes and many of them are held in slavery, without any provisions as to their education or social and intellectual emancipation, often with meagre or no pay. They cook, care for other children in the Homes where they are employed, clean, fetch water, garden and do just about everything else that needs done in the homes where they are employed. A shocking 10.5 million children are estimated to be domestic workers around the world as stated by World Day against Child Labour (2013). They can be found everywhere. Prosecution is difficult as many cultures where the Children live do not have clear cut distinctions between work and family duties, as is the case here in Nigeria. The children are not treated as part of the families in which they are employed and the quantum of work they do is not equivalent to ordinary chores. They are often isolated and subjected to physical and sexual abuse. They are hidden from the outside and utterly dependent on their masters/mistresses. More remote and relative but real is the high incidence of forced child labour in mines and quarries. Mining is known to be strenuous and a very dangerous, high risk undertaking even for adult workers, not to mention children. Yet, in very many parts of our continent, Latin America and Europe, Children are forced to work long hours in mines for little to no pay. They toil in 24 hour-a-time shifts, their growing bodies at risk of being permanently deformed from the strain of carrying heavy loads and metals by crime report (2015). Their toxic systems suffer due to constant dust inhalation, the toxic metals and chemicals do serious damage to their nervous systems.

The Children are kept from school with little or no access to healthcare facilities. The isolated location of most mining sites and quarries contribute to the want of state intervention in this sphere. Child workers can be seen even in Nigeria, in tin and Columbite mining sites in parts of Plateau and Nassarawa States, limestone sites in Ebonyi and Benue States and in stone and steel quarries in Kogi State. Another example of child slavery is seen in the incidence of child prostitution. For decades now, young girls, majority of them aged 14-17 years, have been at the mercy of profitmotivated traffickers who promise them escape routes from poverty and hardship and lure them into prostitution in foreign lands. A healthy number of Nigerian girls suffer this fate in Italy, Russia, the Equatorial Guinea, Gabon and parts of the Islamic Maghreb. These girls are conned into lecherous lives, sex workers in distant lands away from home, promises of a better life and education becoming a mirage. Often, they come to accept their fate seeing how helpless they are, eventually working to attain their freedom from their guardians and growing to begin to earn their own living. This

Copyright () IAARR, 2007-2016: www.afrrevjo.net

Indexed African Journals Online: www.ajo.info 
practice is also prevalent within Nigeria, where traffickers engage children from rural areas onto the cities, at a handsome profit, for the purpose of meeting domestic needs in many urban homes as reported by Daily post (2015). Many of these children, helpless in their predicament, are introduced into working as professional sex workers for profit, deprived education and at the risk of venereal diseases. It is with a view to countering this that the National Agency for the Prohibition of Trafficking in Persons was formed.

Child Slavery is also seen albeit much more remotely in the form of shrine slavery in many parts of West Africa; a ritual servitude carried on in traditional religious circles, with children, especially young virgin girls taken as slaves of the gods, subjected to sexual abuse, forced labour and a life of shame, often without formal education. Then there is the issue of forced, early marriages where under- age girls are given away in marriage against their wishes and without regard for their preferences or happiness. This practice is prevalent in Nigeria as affecting the girl child and ought to be deprecated. Also, children are increasing seen hawking goods and wares in virtually all parts of Nigeria and in many parts of the world, especially in the urban centre. Granted that a minority of them actually do so for self-support, the greater number do so at the instance of a master cum guardian, for little or sometimes no pay at all, deprived of formal education and perpetually exposed to the hazards of the roads. In many parts of the world, practices are being perpetuated subjecting children to lives of slavery and depravity. They additionally include the forceful conscription of child soldiers in armed conflicts in war torn lands, as in Somalia and parts of the Middle East, the engagement of children into forced begging, prevalent in particular in Senegal, the engagement of teenage boys for commercial dancing in Afghanistan, known as Bacha Bazi, the forced engagement of under-age boys as camel jockeys in the Gulf states, the trafficking of children for harvesting of child organs, ${ }^{1}$ e. t. c. Child slavery is real and persistent. The extent of international action with a view to stemming the tide will now be considered.

\section{Child Slavery and the International Community; Legislation, Convention and Positive Action}

The degree of international legislation and instruments in force for the protection of the Interests of Children is noteworthy. The main drawback has always been one of enforcement and reciprocity. It is little wonder then that the UN Universal Declaration of Human Rights (1947) proclaimed that Childhood is entitled to special care and assistance by Universal Declaration of Human Rights (1948). The convention expresses the unanimous resolve of the comity of nations towards the protection of children. It must be noted that Article 4 expresses the general injunction against enslavement of persons, nay children. It provides that "No one shall be held in slavery

\footnotetext{
${ }^{1}$ Ibid
} 
or servitude, slavery and the slave trade shall be prohibited in all their forms." By UDHR (1948). It is also provided that everyone has the right to recognition everywhere as a person before the law. Thus there is the United Nations Convention on the Rights of the Child (1989) which presently has been ratified by 195 member states of the United Nations Nigeria inclusive and which came into force on the $2^{\text {nd }}$ day of September (1989) The convention obliges the contracting parties to honour and guarantee the rights of the Child established therein. By Article 3, state parties undertake to ensure the child such protection and care as is necessary for his or her wellbeing... and to take all appropriate and legislative measures. Article 11 mandates state parties to take measures to combat the illicit transfer and non-return of children abroad. State parties are to take all appropriate legislative, administrative, social and educational measures to protect the child from all forms of physical and mental violence, injury or abuse neglect or negligent treatment, maltreatment or exploitation, including sexual abuse while in the Care of parents, guardians or any other person having care of the child under the CRC (1989). The Convention extensively provides for protection of children, but it does however possess the benign character of international law, the effect of which is that treaties between states are enforceable in honour only. Thus it is one thing for there to be international legislation in check of child slavery and another as to the extent to it can and is actually being checked. More regionally, there is the African Charter on the Rights and Welfare of the Child (1999) which aims to protect the private life of the African child, safeguard him against all forms of economic exploitation and against hazardous work or that which interferes with the child's education or compromises his or her health or physical, social, mental, spiritual and moral development.

It additionally calls for protection against abuse and bad treatment, negative social and cultural practices, all forms of exploitation and sexual abuse including commercial sexual exploitation and it aims to prevent the sale and trafficking of children, kidnapping as well as begging by children. It can be seen that the weight of international action against child slavery is remarkable. However and as has already been noted elsewhere in this paper, the nature of international law and regulation is such that they are mere regulations. Its true strength and force can only be realized in the extent to which they have been domesticated or its principles made to reflect in the spirit and letter of domestic laws, so that it becomes incumbent to examine the provisions of Municipal law as relating to the protection of children from slavery and deprivation, in particular, the laws of Nigeria.

\section{Slavery, Nigerian Law and the Protection of the Child: A Brief Inquiry}

Under the Nigerian legal system, the foremost law is the Constitution of the Federal Republic of Nigeria, (1999) (as amended) It has supreme binding force on all persons and things and it is to it that all other laws must trace their legitimacy, so much so that any law found to be at variance, incompatible or inconsistent with any provision 
of the Constitution will to that extent be null and will be set aside and so pronounced by the supreme courts (1983) The Nigerian Constitution sets the framework for the governance and regulation of lives of the Nigerian people in legal terms. It provides for rights of the citizens, of which children are chiefly among, their duties towards the Nigerian state and inter alia the obligations of the Nigerian state towards its citizens. In particular, Chapter IV of the Constitution provides for the rights of citizens. These rights are stated to be fundamental and thus inalienable. Section 34 guarantees for the dignity of the human person, including children. Accordingly, no person shall be held in slavery or servitude or subjected to inhuman or degrading treatment. Nor shall any person be required to perform forced or compulsory labour. Section 35 guarantees the right of every person, Children inclusive, to their personal liberty, providing that no person shall be deprived of such liberty save in accordance with a procedure permitted by law. The constitution further provides for redress of any of these rights in that it empowers any person who alleges that any of his rights as provided there under is being, has been or is likely to be infringed, to apply to the High Court in that State for redress. Although children under Nigerian ipso facto lack the capacity to institute legal action in their personal capacity with a view to redressing wrongs against them, they can sue through their next friends or guardians as applicable in the various states by the High court civil procedure rules of various state in Nigeria. The spirit and letter of the Nigerian constitution is such that it guards against enslavement or deprivation affecting children. Its provisions are clear on this. The Nigerian courts will readily lend their hands to halt any infringement or breach of those rights. Thus in Badejo Vs. Minister for Education, (1996 p.15) the Court noted inter alia that a citizen's fundamental right is certainly a right that ranks above the ordinary laws of the land and that the courts will avail themselves whenever there has been a breach thereof to set aside such infraction as stated in Solofaham (2002 p.688) It will be imperative to mention in this breadth the Fundamental objectives and directive principles of state policy set out in Chapter II of the Constitution. Section 17(3)f provides that the State shall direct its policy towards ensuring that Children and young persons are protected against any exploitation whatsoever and against moral and material neglect. It is however noted with a tinge of sadness that Chapter II of the Constitution is non-justiciable, so much so that one cannot successfully bring an action in court to ventilate any of the rights or enforce the duties incumbent upon the state thereunder. Suffice it to say that the provisions of that part of the constitution are mere principles of policy or guides with a view to realizing the ideals of the Nigerian State and that more than adequate provisions exist elsewhere in that constitution for the protection of the interests of citizens, and in this context children, especially in Chapter IV (1999) Thankfully, there is a principal legislation specifically providing for the rights and protection of children in Nigeria and that is the Child Rights Act (2003) This statute re-enacts many of the rights set out in Chapter IV of the Constitution but in this case they avail exclusively for the benefit of the Nigerian child. It does go beyond. Thus under the act, the right to 
dignity of the child is guaranteed. Same thing as the right to survival and protection, to parental care, protection and maintenance the act also guarantees the right to free compulsory and universal primary education. There are equally provisions therein guaranteeing the right of a child in need to special care and protection and to protection against abuse and torture. It is in acknowledgement of the fact that the normal rights guaranteed adults are inadequate to accommodate the special needs of children that the child rights law exists. A child has the right to have his best interest considered paramount in any matter concerning him in PART 11 of the Act. It is the intendment of the law that the entire machinery of the state be employed towards the protection of the child. These include the police, the courts, the armed forces and any other special agency set up for the realization of that purpose. The protection of children from the wave of modern day slavery is chiefly among the reasons why the National Agency for the Prohibition of Trafficking in Persons was set up in (2003) with a mandate to address the scourge of trafficking in persons in Nigeria, especially as affecting children and its attendant human abuses in its entire ramifications. Jail terms are provided for as punishment for those convicted of offences relating to trafficking in persons. To what extent the agency has gone in meeting its mandate remains to be seen and we will seek to beam our searchlight on that, albeit cursorily in the ultimate Section of this work.

\section{The State of Positive Action against Child Slavery, Reflections and Conclusion}

Although a lot has been done by the state authorities, international bodies and organisations towards checking the incidence of child slavery in this our day, it cannot be gainsaid that a lot more still needs to be done in that sphere, especially when the certain statistics are put into perspective. Consider the fact that of the 21 to 30 million people estimated to be enslaved around the world, some 5.5 million of the lot are children, with some 600,000 of them found in Nigeria. State agencies like the police and specialised agencies as NAPTIP are clearly not doing enough in plugging the gaps and checking trans- border and inter-state trafficking in young people. It is intriguing, for instance, that in NAPTIP's 12-year existence, it has only succeeded in prosecuting only a disappointing 271 persons to conviction in Nigeria. This is in stark contrast with the wave of activities of traffickers around Nigeria who deal mostly in children. It will be happily noted however that the Police have very greatly upped the ante with the increasing rate of arrests of persons and syndicates illegally dealing in the movement of children for profit making purposes in Nigeria as reported by Punch Newspaper (2015 p.32) On the same plane, it is suggested that stricter measures be put in place towards putting an end to practices such as hawking of wares by children, engagement of child in mines, quarries and mechanical and engineering workshops, imposition of sanctions on erring guardians. Government agencies such as NAPTIP should be strengthened and made to become more effective in the discharge of their functions. This can be done through better funding and the engagement of seasoned, passionate staff. 
Furthermore, child slavery will to a great length be checked if government takes steps towards improving social amenities and infrastructure, especially in the rural areas. This will go to discourage rural urban migration while at the same time reducing to the barest minimum the spate of dealings involving movement of young children onto conditions of slavery mostly prevalent in the urban and cosmopolitan centre. This is chiefly led by the provision of better educational facilities in the rural areas in additional to their being made more affordable and accessible to even the most financially disadvantaged lot of the populace. Regulations should be put in place ensuring that formal education is not just affordable but made compulsory for all children, with sanctions for erring children, parents and guardians. Then there is the need for affirmative action in homes. Guardians and foster-parents in Nigerian homes should be encouraged to be more humane in treatment of their wards. The extent of child enslavement happening discreetly in many Nigerian homes is shocking. It is appalling to see children having to contend with much more domestic work than they ordinarily are capable of filing in at in very many homes. Moderation and reasonableness ought to be the watchwords. It is mostly up to guardians to decide to put a stop to it and tread more justly.

Finally, it is hoped that government, international agencies, non-governmental organisations and families show more commitment to checking modern day slavery of children now prevalent in the land given that if child slavery is stopped, our country and the entire world will undoubtedly be a better place for it. Without these children, there can be no talk of a tomorrow. Tomorrow begins today. The time is now.

\section{References}

African Charter (1999) Articles 16, 21, 22 and 29.

African Charter on the Right and welfare of the Child (1999) Articles 1-8, 10 11, 1215 and 16.

African Charter on the Rights and Welfare of the Child (1999). 1979 African Charter Article 2---- Convention on the Right of the Child (1989)

Child Rights Act (2003). Parts I and II.

Dailypost (Oct. 20, 2015). Police foil trafficking syndicate in Delta and Akwa Ibom States. Retrieved from www.dailpost.ng on Friday OCTOBER 20, 2015.

Federal Republic of Nigeria (1999). Constitution of the Federal Republic of Nigeria, Section 1. Lagos: Federal Government Press.

Freedictionary.com (2015). Slavery. Retrieved November 10, 2015 from www.thefreedictionary.com.

FRN (2004). Cap C22 Laws of the Federation of Nigeria, Section 1 
AFRREV, 10 (1), S/NO 40, JANUARY, 2016

ILO (2013). World Day against Child Labour, 2013. Accessed 12:30pm, 12/11/2015 from www.ilo.org

ILO Global Estimate of Forced Labour (2012). Results and Methodology, www.ilo.org, Accessed 3:55pm, 09/11/2015.

Law Enforcement and Administration Act (2003). Trafficking in Persons (Prohibition)

Listverse.com (n.d). CRIME; 10 Horrifying Examples of Modern Day Slavery. Retrieved from www.listverse.com

Mauritania was the last nation to abolish it in 2007.

Punch Newspaper, 27th October, 2015 at www.punchng.com, Accessed same day at $2 ; 45 \mathrm{pm}$.

Supreme Court of Nigeria (1983). The decision of the Supreme Court of Nigeria in Attorney General of Bendel State and others v Attorney General of the Federation (1983) LPELR SC 108/1982.

Supreme Court of Nigeria (1996). p.15 8 NWLR (PT 464) 15 Badejo vs Minister for Education; See also Sofolahan v Fowler (2002)4 NWLR pt 788. 664 at 688.

UDHR-1948 Article 7.

UN Chronicle; Slavery in the Twenty First Century (PDF), www.un.org. Retrieved 29/8/2010. Accessed 3:50pm, 09/11/2015.

UN UDHR-1948

United Nations (1989). Article 19(1), UN Convention on the Rights of the Child 1989 